\title{
PENGARUH SUHU DAN GENOTIPE PADA VIABILITAS BENIH SORGUM (SORGHUM BICOLOR [L.] MOENCH. ) PASCA SIMPAN 12 BULAN
}

\section{THE EFFECT OF TEMPERATURE AND GENOTYPE IN SORGHUM SEED VIABILITY (Sorghum bicolor [L.] Moench.) POST SAVE 12 MONTHS}

\author{
Nasrulloh Zein Maksum¹, Eko Pramono², Agustiansyah², Yayuk Nurmiaty² \\ ${ }^{1}$ Mahasiswa Jurusan Agroteknologi, Fakultas Pertanian Universitas Lampung \\ ${ }^{2}$ Dosen Jurusan Agroteknologi, Fakultas Pertanian Universitas Lampung, \\ Jln.Prof. Soemantri Brodjonegoro No.1, Bandar Lampung 35145 \\ Email: nasrullohzeynmaksum@gmail.com
}

\begin{abstract}
Sorghum is one of cereal plant that produce carbohydrate.Sorghum has great potential to be developed in Indonesia.Sorghum plants can be used as alternative food, animal feed and bioethanol raw materials. the stock of quality seed and have a long shelf life is an effort to support food diversification in order to provide seeds in the next planting season. The purpose of this study was to determine the effect of storage room temperature and genotype on the viability of post-save sorghum seeds 12 months.This research was conducted at the Seed and Plant Breeding Laboratory, Faculty of Agriculture, University of Lampung, Bandar Lampung, which took place from February 2017 to February 2018. This research used a plot design divided into 3 groups as replications. The main plot is a storage room temperature $(T)$ consisting of low temperature / $18 \pm 1.58^{\circ} \mathrm{C}(\mathrm{T} 1)$ and room temperature / $26 \pm 1.08^{\circ} \mathrm{C}(\mathrm{T} 2)$. Subplot is genotype $(G)$, that consists of Super-1 (G1), Talaga Bodas (G2), GH-3 (G3), and GH-13 (G4). The results showed that sorghum seeds stored for 12 months still had good viability. the seeds that stored at low temperatures (18 $\left.\pm 1.58^{\circ} \mathrm{C}\right)$ can be maintained viability $16 \%$ higher than seeds that stored at room temperature $(26 \pm 1.08$ ${ }^{\circ}$ C). Genotype differences affect the viability of sorghum seeds. The best viability of sorghum seeds after being stored for 12 months is shown by the Super-1 genotype.The superiority of the Super-1 genotype is that it can possibly stored and used for the next season.
\end{abstract}

Keywords: sorghum seed, genotype, storage temperature, seed viability.

\begin{abstract}
ABSTRAK
Sorgum merupakan salah satu jenis tanaman serelia penghasil karbohidrat. Sorgum mempunyai potensi besar untuk dikembangkan di Indonesia. Tanaman sorgum dapat dimanfaatkan sebagai bahan pangan alternatif, pakan ternak dan bahan baku bioethanol. Penyediaan benih bermutu serta memiliki masa simpan panjang merupakan upaya untuk mendukung diversifikasi pangan guna menyediakan benih di musim tanam berikutnya. Tujuan penelitian ini adalah mengetahui pengaruh suhu ruang simpan dan genotipe terhadap viabilitas benih sorgum pasca simpan 12 bulan. Penelitian ini dilaksanakan di Laboratorium Benih dan Pemuliaan Tanaman, Fakultas Pertanian, Universitas Lampung, Bandar Lampung yang berlangsung dari bulan Februari 2017 sampai dengan Februari 2018.
\end{abstract}


Penelitian ini menggunakan rancangan petak terbagi dengan 3 kelompok sebagai ulangan. Petak utama berupa suhu ruang simpan $(\mathrm{T})$ yang terdiri atas suhu rendah $/ 18 \pm 1,58^{\circ} \mathrm{C}(\mathrm{T} 1)$ dan suhu kamar $/ 26 \pm 1,08^{\circ} \mathrm{C}(\mathrm{T} 2)$. Anak petak adalah genotipe (G), yang terdiri dari Super-1 (G1), Talaga Bodas (G2), GH-3 (G3), dan GH-13(G4). Hasil penelitian menunjukkan bahwa benih sorgum yang disimpan selama 12 bulan masih memiliki viabilitas yang cukup baik. Benih yang disimpan pada suhu rendah $\left(18 \pm 1,58^{\circ} \mathrm{C}\right)$ dapat dipertahankan viabilitas $16 \%$ lebih tinggi dari pada benih yang disimpan pada suhu kamar $\left(26 \pm 1,08^{\circ} \mathrm{C}\right)$. Perbedaan genotipe berpengaruh pada viabilitas benih sorgum. Viabilitas benih sorgum yang terbaik setelah disimpan selama 12 bulan ditunjukkan oleh genotipe Super-1. Keunggulan genotipe Super-1 tersebut memungkinkan dapat disimpan dan digunakan untuk musim pertanamaan berikutnya.

Kata kunci: benih sorgum, genotipe, suhu simpan, viabilitas benih.

\section{PENDAHULUAN}

Sorgum ( Sorghum bicolor L. ) merupakan salah satu jenis tanaman serelia penghasil karbohidrat. Sorgum mempunyai potensi besar untuk dikembangkan di Indonesia. Menurut Susilowati dan Saliem (2013), sorgum mempunyai kelebihan berupa memiliki biji dan biomasa tinggi, adaptasi sorgum yang luas sehingga dapat ditanam di hampir semua lahan, toleran terhadap kekeringan, salinitas tinggi dan genangan air, memerlukan lebih sedikit pupuk, mudah dalam budidaya dan dapat diratoon.Penyediaan benih bermutu merupakan upaya untuk mendukung diversifikasi pangan. Kebutuhan benih pada setiap saat musim tanam di tingkat petani menjadi faktor pembatas dalam berproduksi. Jika petani menggunakan benih bermutu rendah maka hasil produksi juga rendah sehingga upaya penyedian pangan alternatif tidak tercapai.

Penyimpanan benih adalah upaya-upaya yang dilakukan untuk mempertahankan viabilitas benih dalam periode simpan tertentu. Hasil penelitian Asih et al. (2017) melaporkan bahwa perbedaan genotipe pada vigor benih sorgum yang disimpan selama 12 bulan dalam ruang penyimpanan dengan suhu $\pm 18^{\circ} \mathrm{C}$ dengan kadar air awal $10 \%$ masih mempunyai viabilitas sebesar 59\%. Penggunaan suhu simpan tersebut menunjukkan pengaruh pada viabilitas akhir benih.

Penggunaan suhu ruang ketika melakukan penyimpanan menjadi faktor yang menentukan umur dari benih tersebut. Menurut Harrington (dalam Justice dan Bass, 1994) setiap penurunan $5^{\circ} \mathrm{C}$ suhu penyimpanan maka umur benih diperpanjang setengahnya. Dengan penggunaan suhu rendah maka umur suatu benih dapat dipertahankan sehingga benih dapat tersedia pada akhir penyimpanan.

Viabilitas benih adalah kemampuan benih untuk tumbuh menjadi kecambah yang ditunjukkan melalui gejala metabolisme atau gejala pertumbuhan (Sadjad, 1994). Viabilitas benih diuji melalui variabel kecepatan perkecambahan, persentase kecambah awal, kecambah normal total, kecambah abnormal dan benih mati.Penyimpanan benih selama 12 bulan bertujuan sebagai upaya penyediaan benih bermutu karena perbedaan pola tanam pada suatu daerah sehingga mengharuskan benih untuk disimpan lebih lama. Selain itu benih juga dapat dimanfaatkan sebagai plasma nutfah bagi pemulia tanaman. Perbedaan genotipe akan 
memberikan respon yang berbeda ketika diberi perlakuan yang sama (Moyo et al., 2015).

Penelitian pengaruh suhu ruang simpan dan genotipe yang berbeda dengan tujuan untuk mengkaji dan mengetaui:(1) Viabilitas benih pada empat genotipe sorgum pasca simpan 12 bulan, (2) Viabilitas benih yang disimpan pada suhu rendah $\left(18 \pm 1,58^{\circ} \mathrm{C}\right)$ dan suhu $\operatorname{kamar}\left(26 \pm 1,08^{\circ} \mathrm{C}\right)$ dari benih sorgum, (3) Viabilitas benih pada genotipe yang disimpan pada suhu rendah $\left(18 \pm 1,58^{\circ} \mathrm{C}\right)$ dan suhu kamar $\left(26 \pm 1,08^{\circ} \mathrm{C}\right)$ pasca simpan 12 bulan.

\section{BAHAN DAN METODE}

Penelitian dilaksanakan di Laboratorium Benih dan Pemuliaan Tanaman Fakultas Pertanian, Universitas Lampung pada bulan Februari 2017 sampai dengan Februari 2018. Alat-alat yang digunakan pada penelitian ini adalah pendingin udara (AC), seed countertipe Seedburo 801, alat pembagi tepat, conductivity metertipe Cyber scan con 11, alat pengukur kadar air tipe GMK, tampah plastik, gelas mineral, alat pengempa kertas, germinator tipe IPB 73 2A/2B, sprayer, klip kertas, amplop kertas, plastik klip, nampan, dan alat tulis. Bahan-bahan yang digunakan pada penelitian ini adalah benih sorgum genotipe Super1, Talaga Bodas, GH-3, GH-13, aquades, kertas merang, air, dan plastik.Penelitian ini menggunakan rancangan percobaan Rancangan Petak Terbagidengan 3 kelompoksebagai ulangan. Petak utama berupa suhu ruang simpan (T) yang terdiri atas suhu rendah/ $18 \pm 1,58^{\circ} \mathrm{C}$ (T1) dan suhu kamar/26 $\pm 1,08^{\circ} \mathrm{C}$ (T2). Anak petak berupa genotipe $(\mathrm{G})$, yang terdiri dari
Super-1 (G1), Talaga Bodas (G2), GH-3 (G3), dan GH-13(G4). Dengan demikian terdapat 8 kombinasi perlakuan dan terdapat 24 satuan percobaan.

Pemanenan dan persiapan benih dimulai dari bulan Januari 2017. Benih sorgum berasal dari pertanaman di Desa Tulung Agung, Kecamatan Gading Rejo, Kabupaten Pringsewu. Genotipe benih yang digunakan adalah Super-1, Talaga Bodas, GH-3 dan GH-13.Benih sorgum yang telah dirontokkan dimasukkan kedalam wadah amplop kertas yang kemudian dimasukan kedalam oven tipe memmert. Pengeringan dilakukan dengan suhu $40^{\circ} \mathrm{C}$ selama 32 jam agar embrio pada benih tidak mati. Pengeringan dilakukan sampai kadar air turun menjadi 8\%.

Benih sorgum yang sudah mencapai kadar air sebesar $8 \%$ selanjutnya didinginkan pada desikator. Benih dikemas ke dalam plastik klip dengan jumlah 130 butir/plastik kemudian udara didalam plastik dikeluarkan lalu direkatkan penutup plastik. Setelah itu, masing-masing plastik sampel diberi label sesuai dengan perlakuan, penggunaan wadah ini bertujuan untuk menjaga agar kadar air stabil dan tidak meningkat ketika dilakukan penyimpanan diruang simpan.

Pengujian awal dilakukan sebelum menyimpanan benih ke dalam masing-masing ruang penyimpanan. Pengujian awal bertujuan untuk mengetahui nilai per variabel yang diuji sebelum dan sesudah penyimpanan selama 12 bulan. Berikut disajikan data pengujian awal sebelum penyimpanan (Tabel 2).

Benih yang sudah dikemas ke dalam plastik klip kemudian disimpan dengan menempatkan kantung 
benih pada nampan dengan dibagi kedalam 3 blok, kemudian nampan ditutup. Benih disimpan pada 2 macam ruang penyimpanan, yaitu suhu ruang $18 \pm 1,58^{\circ} \mathrm{C}$ dan suhu ruang $26 \pm 1,08^{\circ} \mathrm{C}$. Pengukuran viabilitas dilakukan pada benih yang telah disimpan selama 12 bulan. Viabilitas benih diukur dengan uji perkecambahan benih, benih dikecambahkan didalam germinator dengan suhu $28,17 \pm 1,79^{\circ} \mathrm{C}$ dan kelembaban 99\% kemudian dilakukan pengamatan pada hari ke 2, 3, 4, dan 5 setelah dikecambahkan.

Uji perkecambahan benih dilakukan dengan menggunakan metode uji kertas digulung didalam plastik
(UKdP) menggunakan kertas merang. Kertas merang direndam dengan airkemudian dikempa sampai kondisi lembab. Setiap gulungan kertas terdapat empat lembar kertas merang dan satu lembar plastik, sebanyak dua lembar untuk alas dan dua lembar sebagai penutup (ISTA, 2009). Setiap gulungan ditanam benih sebanyak 25 butir dan dilakukan pengulangan sebanyak tiga kali. Setiap gulungan diberi label sesuai dengan masingmasing perlakuan kemudian dimasukkan ke dalam alat pengecambah benih tipe IPB 73-2A/2B. Pengamatan dilakukan pada hari ke dua setelah pengecambahan sampai hari ke lima. Pengamatan darimetode ini adalah

Tabel 2. Data nilai pengujian awal sebelum penyimpanan sorgum ( 0 bulan)

\begin{tabular}{lccccc}
\hline \multirow{2}{*}{\multicolumn{1}{c}{ Variabel Pengamatan }} & \multicolumn{4}{c}{ Nilai Pengujian Genotipe } & \multirow{2}{*}{ Rata-rata } \\
\cline { 2 - 5 } & Super-1 & $\begin{array}{l}\text { Talaga } \\
\text { Bodas }\end{array}$ & GH-3 & GH-13 & \\
\hline Kecambah Normal Total (\%) & 96 & 92.67 & 94 & 94 & 94.17 \\
Kecambah Abnormal (\%) & 1.33 & 6 & 2.67 & 1 & 2.75 \\
Benih Mati (\%) & 2.67 & 1.33 & 1.33 & 5 & 2.58 \\
Kecepatan Perkecambahan (\%/hari) & 40.8 & 30.07 & 34.17 & 30.43 & 33.87 \\
Daya Hantar Listrik $\left(\mu \mathrm{S} . \mathrm{Cm}^{-1}\right)$ & 90.33 & 148.93 & 146.07 & 194.07 & 144.85 \\
Kadar Air(\%) & 8,2 & 8,1 & 8,1 & 8,0 & 8,1 \\
\hline
\end{tabular}

Tabel 1. Rangkuman hasil analisis ragam pengaruh suhu dan genotipe pada viabilitas benih sorgum (Sorghum bicolor [L]. Moench.) pasca simpan 12 bulan.

\begin{tabular}{|c|c|c|c|}
\hline \multirow{2}{*}{ Variabel } & \multicolumn{3}{|c|}{ Perlakuan } \\
\hline & $\mathrm{T}$ & $\mathrm{G}$ & $\mathrm{T} \times \mathrm{G}$ \\
\hline Kecambah Normal Total (\%) & $*$ & $*$ & tn \\
\hline Kecepatan Perkecambahan (\%/hari) & $*$ & $*$ & tn \\
\hline Benih Mati (\%) & $*$ & $*$ & tn \\
\hline Kecambah Abnormal (\%) & tn & tn & tn \\
\hline Kadar Air setelah penyimpanan (\%) & tn & $*$ & tn \\
\hline Daya Hantar Listrik $\left(\mu \mathrm{S} . \mathrm{Cm}^{-1}\right)$ & tn & $*$ & tn \\
\hline
\end{tabular}

Keterangan: T : Suhu Ruang Simpan; G: Genotipe; T x G: Interaksi Suhu Ruang Simpan dengan Genotipe; *: Berbeda nyata pada $\alpha=0,05$; tn: Tidak berbeda nyata pada $\alpha=0,05$. 
Kecambah Normal Total (KNT), Kecepatan Perkecambahan (KP), Benih Mati (BM), dan Kecambah Abnormal (KAN). Kadar air benih diukur dengan metode tidak langsung menggunakan alat pengukur kadar air tipe GMK-308 (ISTA,2009).

Sebanyak 5 butir benih sorgum diletakkan pada penampung benih kemudian dimasukkan ke dalam alat tersebut, lalu tuas penghancur benih diputar sampai benih hancur. Kemudian pilih mode pengujian sesuai dengan benih yang akan diuji, lalu pilih measure. Nilai kadar air benih akan ditampilkan pada monitor alat tersebut.

Pengukuran daya hantar listrik dilakukan untuk mengetahui tingkat kebocoran membrane sel. Pengujian
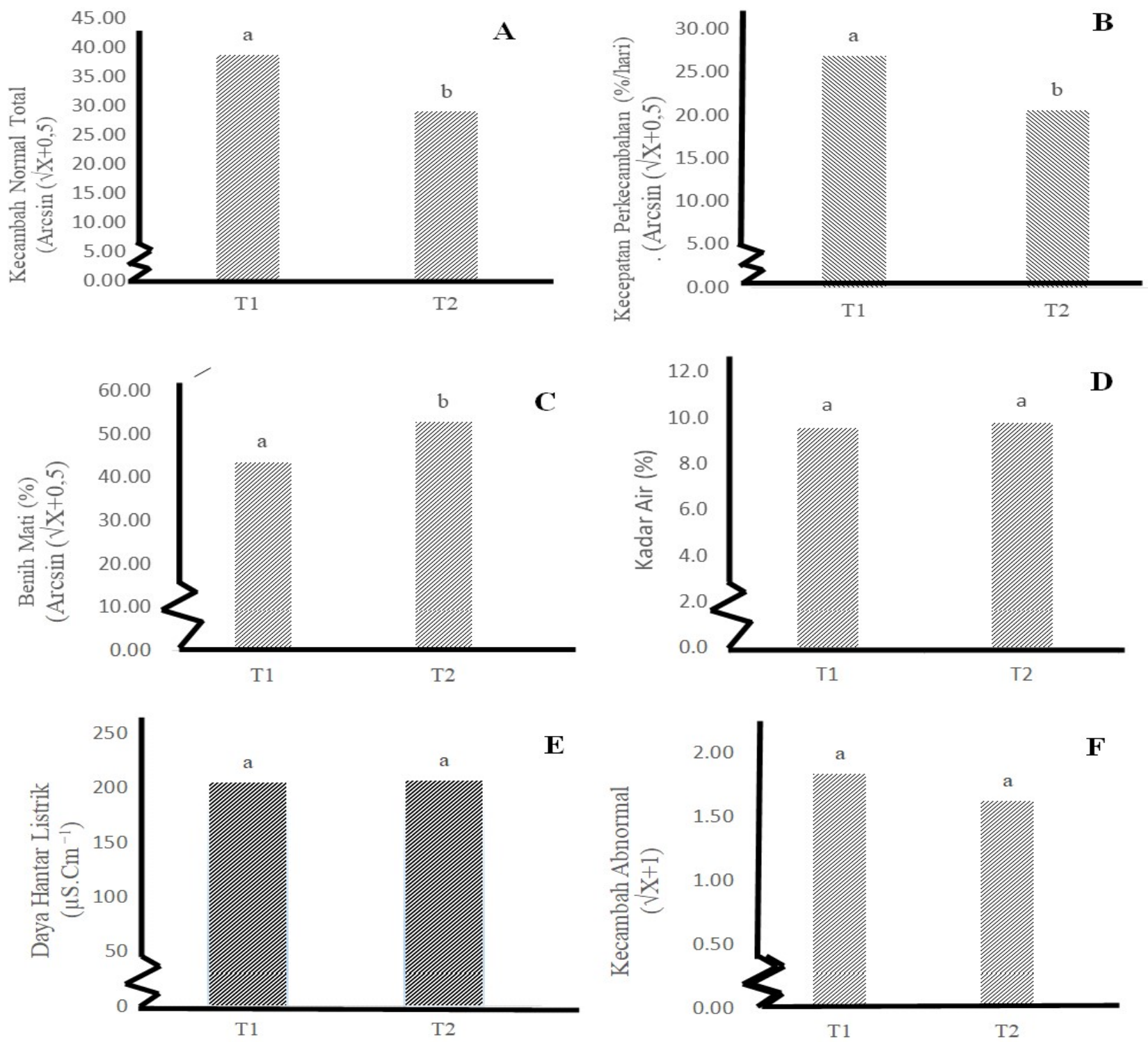

Gambar 1. Kecambah normal total (A), Kecepatan perkecambahan (B), Benih Mati (C), Kadar air (D), Daya Hantar Listrik (E), Kecambah Abnormal (F); T1 $\left(18 \pm 1,58^{\circ} \mathrm{C}\right), \mathrm{T} 2\left(26 \pm 1,08^{\circ} \mathrm{C}\right.$; Nilai tengah yang diikuti oleh huruf yang sama tidak berbeda nyata berdasarkan Uji Beda Nyata Jujur pada $\alpha=0,05$ 
dilakukan dengan cara merendam sebanyak 25 butir benih sorgum kedalam $50 \mathrm{ml}$ aquades. Gelas plastik yang berisi sampel rendaman ditutup menggunakan plastic dan didiamkan selama 24 kemudian dilakukan pengukuran menggunakan alat tipe Condictivity meter con-700. Pengukuran dilakukkan dengan mengkalibrasi sensor pembaca dengan larutan $\mathrm{KCl}$ kemudian dibilas dengan aquades lalu dicelupkan ke dalam gelas sampel. Nilai daya hantar listrik akan ditampilkan pada monitor alat tersebut.
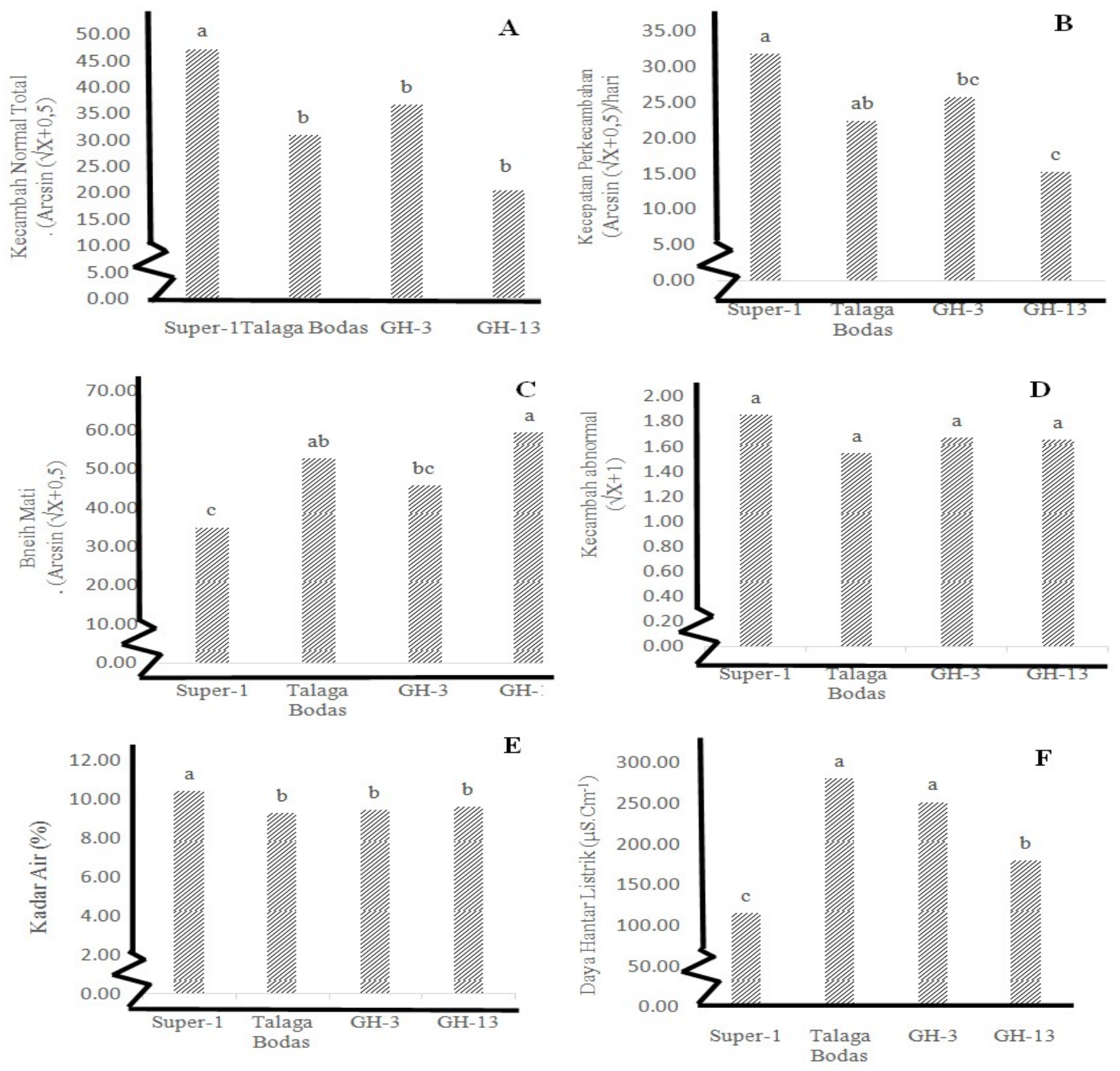

Gambar 2. Kecambah normal total (A), Kecepatan perkecambahan (B), Benih Mati (C), Kecambah abnormal(D), Kadar air (E), Daya Hantar Listrik(F); Nilai tengah yang diikuti oleh huruf yang sama tidak berbeda nyata berdasarkan Uji Beda Nyata Jujur pada $\alpha=0,05$ 


\section{HASIL DAN PEMBAHASAN}

Rekapitulasi analisis ragam pengaruh suhu ruang simpan dan penggunaan genotipe yang berbeda pada penyimpanan selama 12 bulan menunjukkan hasil nyata pada viabilitas benih sorgum yang ditunjukkan oleh kecambah normal total, kecepatan perkecambahan, benih mati dan kadar air setelah penyimpanan. Akan tetapi nilai viabilitas benih sudah rendah karena pengaruh lama simpan 12 bulan.

Pada variabel pengamatan kecambah normal total, pengaruh suhu simpan menunjukkan bahwa suhu simpan rendah $\left(18 \pm 1,58^{\circ} \mathrm{C}\right)$ memiliki nilai lebih tinggi sebesar $16 \%$ dari pada suhu kamar $\left(26 \pm 1,08^{\circ} \mathrm{C}\right)$. Variabel kecepatan perkecambahan memiliki selisih $6,32 \% /$ hari lebih tinggi pada suhu rendah $\left(18 \pm 1,58^{\circ} \mathrm{C}\right)$ sedangkan pada variabel benih mati memiliki selisih 9,33\% lebih besar suhu kamar dibandingkan dengan suhu rendah.Penelitian ini menunjukkan bahwa perbedaan suhu ruang penyimpanan nyata pada variabel kecambah normal total, kecepatan perkecambahan, dan benih mati. Hal ini diduga disebabkan karena pengaruh suhu rendah pada ruang penyimpanan. Suhu rendah pada ruang penyimpanan akan mempertahankan mutu benih setelah disimpan. Persentase kecambah normal total dan kecepatan perkecambahan lebih tinggi pada benih yang disimpan di suhu rendah dibandingkan dengan benih yang disimpan pada suhu kamar. Sedangkan persentase benih mati lebih tinggi pada ruang suhu kamar dibandingkan dengan suhu rendah. Hal ini sesuai dengan penelitian Rahayu (2007), kecepatan perkecambahan merupakan indikator vigor, benih yang disimpan pada ruang Air conditioner dan kulkas dapat dipertahankan sampai akhir masa simpan dan memiliki persentase kecepatan perkecambahan yang lebih besar dari benih yang disimpan pada suhu kamar.

Perbedaan suhu ruang simpan nyata dalam mengakibatkan kemunduran benih yang ditunjukan pada variabel benih mati. Hal ini karena suhu penyimpanan benih sorgum akan mempengaruhi laju kemunduran benih sorgum. Hal ini sesuai dengan hukum Harrington (dalam Justice dan Bass, 1994), semakin rendah suhu penyimpanan maka semakin rendah laju kemunduran benih yang disimpan. Kemunduran benih juga ditandai dengan meningkatnya benih mati. Kondisi ruang penyimpanan yang bersuhu tinggi akan mempercepat reaksi metabolisme benih dan meningkatnya persentase benih mati yang terlihat dari indikasi laju kenaikan kadar air akan berlangsung lebih cepat. Hal ini sesuai dengan pernyataan Purwanti (2004) bahwa tinggi atau rendahnya kadar air benih disebabkan oleh kondisi ruang simpan dan lama penyimpanan.

Pengaruh genotipe nyata pada variabel kecambah normal total, kecepatan perkecambahan, benih mati, kadar air setelah penyimpanan dan daya hantar listrik. Pada variabel kecambah total dan kecepatan perkecambahan, genotipe Super-1 menunjukkan yang paling unggul yaitu $47,22 \%$ dan 20,28\%/hari. Genotipe GH-13 memiliki viabilitas paling rendah yang ditunjukkan oleh variabel benih mati paling besar yaitu 59,33\%.

Penelitian ini menunjukkan bahwa pengaruh genotipe yang berbeda mengakibatkan nyata pada kemunduran benih sorgum. Hal ini disebabkan oleh 
perbedaan faktor genetik bawaan pada masing-masing genotipe. Perbedaan faktor genetik yang dimiliki akan memberikan respon yang berbeda terhadap kemunduran dan mutu benih setelah penyimpanan. Hal tersebut sejalan dengan pernyataan Mangoendidjojo (2008) perbedaan genotipe akan menyebabkan perbedaan bentuk dan sifat biji sehingga akan mempengaruhi mutu benih setelah penyimpanan. Hasil penelitian Nuraini (2018) mendukung pernyataan tersebut, bahwa perbedaan nilai daya hantar listrik yang berbeda pada masing-masing genotipe disebabkan oleh karakter genetik yang berbeda pada masingmasing genotipe yang memungkinkan benih memiliki tingkat permeabilitas kulit yang berbeda pula.

Berdasarkan hasil penelitian diketahui genotipe Super-1 memiliki nilai daya hantar listrik paling rendah akan tetapi memiliki nilai kadar air yang tinggi dibandingkan dengan Talaga Bodas, GH-3 dan GH13. Hal tersebut diduga disebabkan oleh tingkat kekerasan benih Super-1 yang rendah, hal ini sesuai dengan penelitian Hakim (2017) yang menyatakan bahwa genotipe Super-1 memiliki tingkat kekerasan paling rendah dibandingkan dengan dengan genotipe Super-1, GH-6, dan P/5-193C. Kadar air yang tinggi juga disebabkan oleh suhu ruang kamar pada ruang penyimpanan, hal ini karena suhu dan kelembaban akan mempengaruhi kadar air benih saat penyimpanan, hal ini sejalan dengan hasil penelitian Dewi (2002), yang menyatakan bahwa benih yang dsimpan pada suhu kamar mengalami pengingkatan kadar air secara cepat karena pada suhu tinggi benih mengalami laju respirasi lebih cepat dibandingkan dengan benih yang disimpan pada AC dan kulkas. Hal tersebut sesuai dengan pernyataan Idris (2010), yang menyatakan kadar air akan meningkat sesuai dengan kelembaban udara disekitarnya, jika kelembaban udara meningkat maka kadar air benih meningkat dan begitu sebaliknya jika kelembaban benih menurun kadar air akan menurun.

\section{KESIMPULAN}

Hasil penelitian disimpulkan bahwa benih sorgum yang disimpan selama 12 bulan masih memiliki viabilitas yang cukup baik. Benih yang disimpan pada suhu rendah $\left(18 \pm 1,58^{\circ} \mathrm{C}\right)$ dapat dipertahankan viabilitas $16 \%$ lebih tinggi dari pada benih yang disimpan pada suhu kamar $\left(26 \pm 1,08^{\circ} \mathrm{C}\right)$. Viabilitas benih sorgum yang terbaik setelah disimpan selama 12 bulan ditunjukkan oleh genotipe Super-1.

\section{DAFTAR PUSTAKA}

Asih, N.W.A.S., P.B.Timotiwu., E. Pramono and Agustiansyah. 2017. Effect of Storage Periods on Physical Quality and Seed Vigor of Four Varieties of Sorghum. ( Sorghum bicolor [L]. Moench ). Research in Agriculture Journal 2(2): 30-40.

Dewi, M. 2002. Pengaruh Kondisi Ruang Simpan dan Jenis Kemasan terhadap Viabilitas Benih Kangkung Darat (Ipomea Reptans Poir) pada beberapa Periode Simpan. Skripsi. Fakultas Pertanian. Institut Pertanian Bogor. Bogor.

Hakim, F.A. 2017. Pengaruh Genotipe Pada Produksi Dan Mutu Benih Sorgum (Sorghum bicolor [L.] Moench) Pasca Simpan 3 Dan 9 Bulan. Skripsi. Universitas Lampung. Lampung. 
Idris dan A.A.K. Sudharmawan. 2010. Pengaruh Umur Panen terhadap Viabilitas Benih Kedelai varietas Wilis. J. Crop Agro.3(2):88-91.

ISTA. 2009. International Rules for Seed Testing. Third Edition. International Rules for Seed Testing Association. Zurich.

Justice, O.L., dan L.N. Bass. 1994. Prinsip dan Praktik Penyimpanan Benih. Diterjemahkan Rennie Roesli. Raja Grafindo. Jakarta. Terjemah dari: Principle and Practices os Seed Storage

Mangoendidjojo, W. 2008. Dasar-Dasar Pemuliaan Tanaman. Kanisius. Yogyakarta. $182 \mathrm{hlm}$

Moyo, R., E. Ndlovu, N. Moyo, M. Maphosa. 2015. Physiological parameters of seed vigour in ex situ stored sorghum germplasm. J. Cereals oilseeds.(6) 6:31-38.

Nuraini, A., S. Sumadi, M. Kadapi, A. Wahyudin, D. Ruswandi, M.N. Anindya. 2018. Evaluasi Ketahanan Simpan Enam Belas Genotip Benih Jagung Hibrida Unpad pada Periode Simpan Empat Bulan. Jurnal Kultivasi 17 (1):568575 .

Purwanti, S. 2004. Kajian Suhu Ruang Simpan terhadap Kualitas Benih Kedelai Hitam dan Kedelai Kuning. Jurnal Imu Pertanian 11(1) :22-31.

Rahayu, E. dan E. Widajati. 2007. Pengaruh Kemasan, Kondisi Ruang Simpan dan Periode Simpan Terhadap Viabilitas Benih Caisin (Brassica chinensis L.). Bul. Agronomi. 35 (3) : 191196.

Sadjad, S. 1994. Dari Benih Kepada Benih. Gramedia Widiasarana. Jakarta. $144 \mathrm{hlm}$.
Susilowati, S.H.dan H.P. Saliem. 2013. Sorgum Inovasi Teknologi dan Pengembangan:Perdagangan Sorgum di Pasar Dunia dan Asia serta Prospek Pengembangannya di Indonesia. IAARD Press Badan Penelitian dan Pengembangan Pertanian. Jakarta. $17 \mathrm{hlm}$. 